\title{
BIOLOGICAL AND HISTORICAL FACTORS INFLUENCING GENETIC DIVERSITY IN THE SCUTELLARIA ANGUSTIFOLIA COMPLEX (LABIATAE)
}

\author{
RICHARD G. OLMSTEAD ${ }^{1}$ \\ Department of Biology, University of Michigan, Ann Arbor, MI 48109
}

\begin{abstract}
Studies of genetic diversity at isozyme loci were used to examine the phylogenetic distribution of several frequently reported population-genetic parameters in a putatively monophyletic group of plant species, the Scutellaria angustifolia complex. The influence of taxon-specific differences in habitat preference, breeding system, degree of endemism, and phylogenetic relatedness was examined. Many characters of reproductive morphology traditionally used in phylogenetic inference vary with breeding system. To the extent that reproductive systems are conservative markers of phylogenetic relationships, one would expect the distribution of genetic variation to be similar in closely related taxa. Results showed that closely related taxa may exhibit very different genetic-diversity statistics and that distantly related taxa may exhibit very similar genetic-diversity statistics. This suggests that complex patterns of evolution of breeding systems and morphological characters have occurred in the ten taxa included in the Scutellaria angustifolia complex. Similarity in habitat is not associated with similarity in genetic diversity in this group of species.
\end{abstract}

Received May 4, 1988. Accepted September 28, 1989

Relatively little is known about the genetic structure of entire clades (i.e., monophyletic assemblages of species) and what factors result in differences that are observed in genetic structure among species within a clade. Most studies of genetic structure in plant populations and species have been conducted on single species (Gottlieb, 1974; Hiebert and Hamrick, 1983; Wendel and Parks, 1985; Soltis and Soltis, 1987) or pairs of closely related species for which a particular relationship is postulated: progenitor/derivative (Gottlieb, 1973; Crawford and Smith, 1982a; Gottlieb et al., 1985), outcrosser/selfer (Brown and Jain, 1979; Gottlieb, 1984), diploid/polyploid (Crawford and Smith, 1984; Bayer and Crawford, 1986), or sister species (Crawford and Smith, $1982 b$; Layton and Ganders, 1984; Rieseberg and Soltis, 1987). Knowledge of genetic variability in rare or endemic species is important for conservation genetics; consequently, species with restricted distributions have been studied genetically, in some cases in conjunction with more widespread sister species (Schonewald-Cox et al., 1983; Karron, 1987). Many reviews have emphasized breeding systems or ecological determinants in relation to genetic structure of

\footnotetext{
1 Present address: Department of Biology, Indiana University, Bloomington, IN 47405.
}

populations and species (Gottlieb, 1981; Hamrick et al., 1979; Nevo et al., 1984; Loveless and Hamrick, 1984).

The relative importance of variation in habitat type, reproductive biology, extent of geographic distribution, and phylogenetic relatedness to the differences in genetic structure among plant species can be studied best in a monophyletic species group in which variation exists for all of these potential influencing factors. By studying individual species or pairs of sister species, the relative importance of these variables remains obscure. Phylogenetic groups of plant species that have been studied genetically often represent special cases. Speciesgroups restricted to oceanic islands tend to be genetically homogeneous and little differentiated (Lowrey and Crawford, 1985; Helenurm and Ganders, 1985; Crawford et al., 1987). Mainland species-groups that have been examined electrophoretically have consisted primarily of species that are ecologically and reproductively similar (Crawford and Wilson, 1979; Bruederle and Fairbrothers, 1986; Manos and Fairbrothers, 1987), so that the relative importance of ecology, reproductive biology, and phylogenetic history cannot be interpreted.

This paper presents the results of an electrophoretic study of the genetic diversity and population structure in the Scutellaria angustifolia complex, a putatively monophy- 
letic group of ten taxa native to western North America (Table 1). Variation in breeding system, habitat specificity, and degree of endemism among the taxa provides the opportunity to examine the effect of these three factors on the extent and distribution of genetic diversity within and among species of the group. An analysis of phylogenetic relationships within the group (Olmstead, 1989) also enables one to examine the genetic variability among the ten taxa within a phylogenetic context to determine whether similarity in levels of genetic diversity is associated with phylogenetic relatedness.

Plants in the $S$. angustifolia complex are herbaceous perennials occurring in small, widely scattered populations. Taxa in the group have a wide range of habitat specificities (Table 1), from wet streamside habitats to sagebrush desert and chaparral. Geographic distributions vary from taxa that are widespread throughout California or the Great Basin to narrowly restricted taxa in each of the two regions. Variation in corolla size among taxa in the complex is associated with differences in the amount of autogamous seed set (Olmstead, 1988): taxa with small flowers exhibit a high degree of autogamous seed set, whereas the large-flowered taxa exhibit essentially none, suggesting that natural populations of these taxa differ markedly in the degree of selfing and outcrossing. The small isolated nature of the populations in the complex and the lack of any apparent long-distance seed-dispersal mechanism suggest that the taxa in the group are characterized by small effective population sizes with very limited gene flow among populations. All taxa are diploid with $2 n=24$ or $2 n=22$ chromosomes.

\section{MATERIALS AND METHODS}

Population Sampling.-Plants sampled for the isozyme studies were collected as rhizomes from a total of 106 populations throughout the distribution of the Scutellaria angustifolia complex in western North America (Fig. 1, Appendix) and grown in the greenhouse at the University of Washington. Rhizomes were sampled so as to minimize collecting clonal replicates; 5-20 individuals were sampled from each population, except for populations in which the small population size limited the possible sample size. The large number of populations sampled (relative to most studies of plant genetic diversity) and the relatively small average sample size represent a tradeoff designed to make feasible a study of ten taxa composed of small isolated populations throughout a large geographic range. All population samples for each taxon (Table 1) are used in subsequent analyses of population-genetic statistics, except where otherwise noted. Vouchers for all populations are deposited in the herbarium at the University of Washington.

Electrophoretic Analysis.-Starch-gel electrophoresis was performed using young leaves and stem apexes. The extraction buffer was $0.1 \mathrm{M}$ tris- $\mathrm{HCl}, \mathrm{pH} 7.5,0.001 \mathrm{M}$ EDTA, $0.01 \mathrm{M} \mathrm{KCl}, 0.01 \mathrm{M} \mathrm{MgCl}, 8 \%$ (wt./ vol.) PVP 40,000, with $0.1 \%$ (vol./vol.) 2-mercaptoethanol added just before beginning the extraction (Soltis et al., 1983). Filter-paper wicks were soaked in the extracts and inserted into $12.5 \%$ starch gels. Three buffer systems were used to resolve nine enzyme systems. Aspartate amino transferase (AAT), fluorescent esterase (FE), phosphoglucose isomerase (PGI), and triose phosphate isomerase (TPI) were resolved using a lithium-borate buffer system: gel buffer = $0.004 \mathrm{M} \mathrm{LiOH}, 0.029 \mathrm{M}$ boric acid, 0.033 $\mathrm{M}$ tris, and $0.005 \mathrm{M}$ citric acid, $\mathrm{pH} 8.0$; electrode buffer $=0.039 \mathrm{M} \mathrm{LiOH}$ and 0.263 $\mathrm{M}$ boric acid, $\mathrm{pH} 8.0$ (modification of number 8 of Soltis et al. [1983]). Aconitase (ACN), isocitrate dehydrogenase (IDH), malate dehydrogenase (MDH), phosphoglucose isomerase (PGI), and phosphoglucomutase (PGM) were resolved on a continuous histidine-citric-acid buffer system: gel buffer $=0.009 \mathrm{M}$ L-histidine, $0.002 \mathrm{M}$ citric acid, $\mathrm{pH} 6.0$; electrode buffer $=0.065$ M L-histidine, $0.016 \mathrm{M}$ citric acid, pH 6.0 (number 9 of Soltis et al. [1983]). Shikimate dehydrogenase (SkDH) was resolved on a discontinuous buffer system: gel buffer = $0.02 \mathrm{M}$ histidine- $\mathrm{HCl}, \mathrm{pH} 7.0$; electrode buffer $=0.4 \mathrm{M}$ citric acid, trisodium salt, pH 7.0 (number 1 of Soltis et al. [1983]). Gels were stained according to the procedures of Soltis et al. (1983). For each enzyme, gene loci and isozymes were labelled $1,2,3$, etc., and for each locus, alleles and allozymes were labeled a, b, c, etc., begin- 


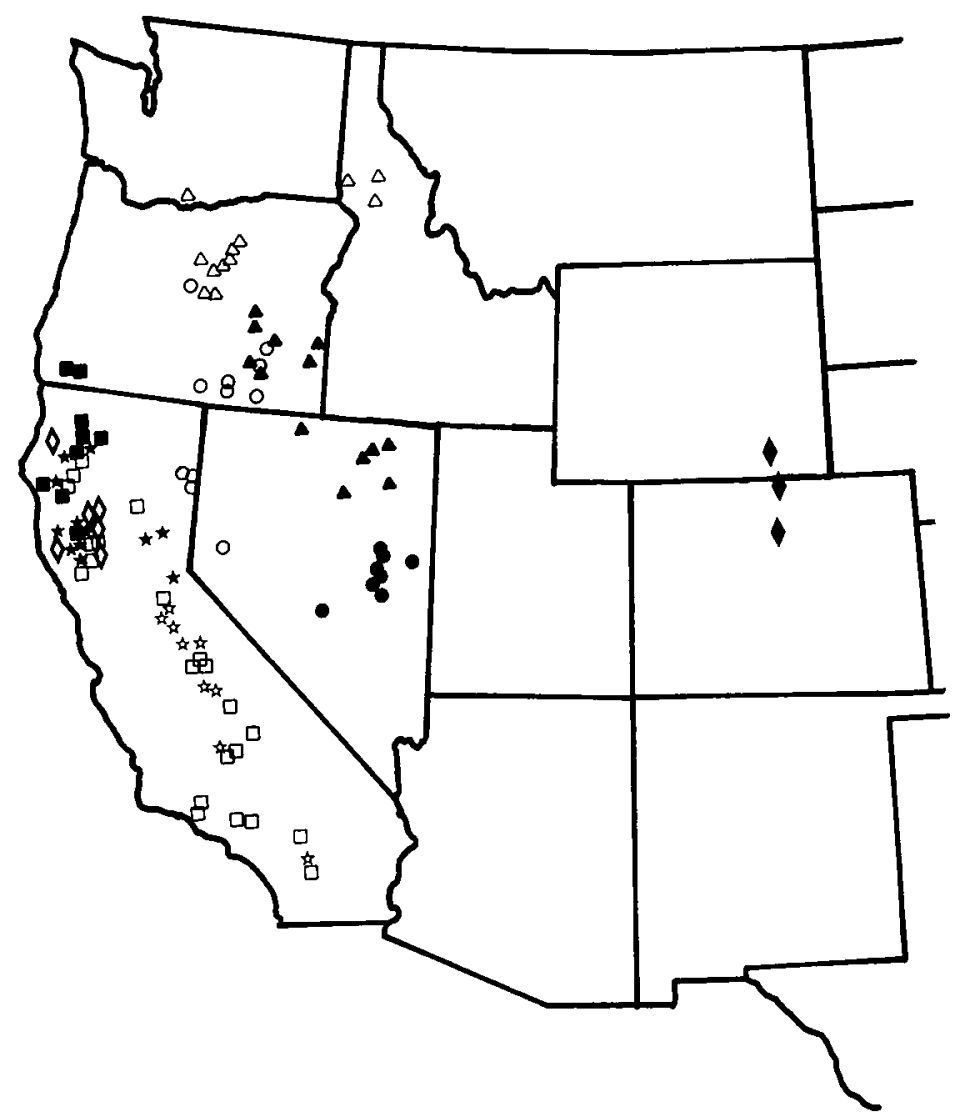

FIG. 1. Distribution of the 106 populations sampled for the electrophoretic analysis of the Scutellaria angustifolia complex. For locality information, see Appendix. Symbols: $\Delta=S$. angustifolia angustifolia, $\boldsymbol{\Delta}=S$.

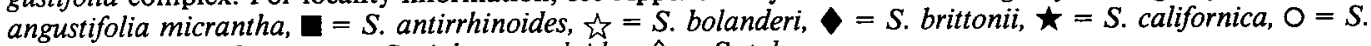
nana, $=S$. sapphirina, $\square=S$. siphocampyloides, $\diamond=S$. tuberosa.

ning with the most-anodally migrating bands.

Data Analysis. - Data consisted of allozyme genotypes for each individual for all loci sampled. Genetic-variability statistics including allele frequency, number of alleles per locus, percentage of polymorphic loci, percentage heterozygosity, hierarchical $F$ statistics for the apportionment of genetic diversity (Nei, 1973), and genetic identity (Nei, 1978) were calculated using BIOSYS-1 (Swofford and Selander, 1981). The effective number of alleles $\left(n_{\mathrm{e}}\right)$ was calculated following Kimura and Crow (1964):

$$
n_{\mathrm{c}}=\frac{1}{\sum_{i=1}^{n} \hat{p}^{2}}
$$

where $n$ is the number of alleles detected and $p$ is the allele frequency. Wright's (1951) fixation index, $F$, is a function of observed and expected heterozygosities: $F=\left(H_{\mathrm{e}}-\right.$ $\left.H_{\mathrm{o}}\right) / H_{\mathrm{e}} . F$ was calculated only for populations with sample sizes of eight or greater and with two or more polymorphic loci. Within-population statistics and hierarchical $F$ statistics were calculated only for population samples with five or more individuals.

\section{RESULTS}

Nine enzymes encoded by 18 gene loci provided consistently interpretable results for all populations (Table 2). Several additional loci were not included because they could not be resolved uniformly in all populations ( $F e-2, L a p-1$, and $P g i-1)$ or could not be interpreted readily due to overlap- 
TABLE 1. Number of populations sampled, distribution, habitat, and breeding system for each of the ten taxa in the Scutellaria angustifolia complex.

\begin{tabular}{|c|c|c|c|c|}
\hline Taxon & $\begin{array}{l}\text { Number } \\
\text { of popu- } \\
\text { lations } \\
\text { sampled }\end{array}$ & Distribution & Habitat & Breeding system \\
\hline $\begin{array}{l}\text { S. angustifolia } \\
\text { Pursh ssp. angus- } \\
\text { tifolia }\end{array}$ & 12 & $\begin{array}{l}\text { eastern WA, OR, } \\
\text { and adjacent ID }\end{array}$ & $\begin{array}{l}\text { ponderosa pine wood- } \\
\text { land; basalt derived } \\
\text { substrate }\end{array}$ & $\begin{array}{l}\text { long-flowered; outcross- } \\
\text { ing }\end{array}$ \\
\hline $\begin{array}{l}\text { S. angustifolia } \\
\text { Pursh ssp. mi- } \\
\text { crantha Olm- } \\
\text { stead }\end{array}$ & 13 & $\begin{array}{l}\text { northern Great } \\
\text { Basin (OR, NV, } \\
\text { and ID) }\end{array}$ & $\begin{array}{l}\text { pinyon/juniper, sage- } \\
\text { brush; basalt substrate }\end{array}$ & short-flowered; selfing \\
\hline $\begin{array}{l}\text { S. antirrhinoides } \\
\text { Benth. }\end{array}$ & 9 & $\begin{array}{l}\text { northern } \mathrm{CA} \text { and } \\
\text { adjacent } \mathrm{OR}\end{array}$ & $\begin{array}{l}\text { openings in mixed coni- } \\
\text { fer woodlands; var- } \\
\text { ious substrates }\end{array}$ & short-flowered; selfing \\
\hline S. bolanderi Gray & 10 & $\begin{array}{l}\text { CA; Sierra Neva- } \\
\text { da foothills; } \\
\text { southern CA } \\
\text { mountains }\end{array}$ & $\begin{array}{l}\text { pine/oak woodlands; } \\
\text { streamside gravel }\end{array}$ & $\begin{array}{l}\text { short-flowered; some } \\
\text { selfing }\end{array}$ \\
\hline S. brittonii Porter & 3 & $\begin{array}{l}\text { Rocky Mt. front } \\
\text { range (WY, CO, } \\
\text { and } \mathrm{NM})\end{array}$ & $\begin{array}{l}\text { ponderosa pine wood- } \\
\text { land; granite substrate }\end{array}$ & $\begin{array}{l}\text { long-flowered; outcross- } \\
\text { ing }\end{array}$ \\
\hline S. californica Gray & 12 & $\begin{array}{l}\text { CA; North Coast } \\
\text { Range; northern } \\
\text { Sierra Nevada }\end{array}$ & $\begin{array}{l}\text { mixed conifer/oak } \\
\text { woodland; various } \\
\text { substrates }\end{array}$ & $\begin{array}{l}\text { short-flowered (white); } \\
\text { outcrossing }\end{array}$ \\
\hline S. nana Gray & 11 & $\begin{array}{l}\text { northern Great } \\
\text { Basin (CA, NV, } \\
\text { OR, and ID) }\end{array}$ & $\begin{array}{l}\text { sagebrush desert; basalt } \\
\text { substrate }\end{array}$ & $\begin{array}{l}\text { short-flowered (white); } \\
\text { outcrossing }\end{array}$ \\
\hline $\begin{array}{l}\text { S. sapphirina (Bar- } \\
\text { neby) Olmstead }\end{array}$ & 8 & central Nevada & $\begin{array}{l}\text { sagebrush desert; on and } \\
\text { off basalt }\end{array}$ & short-flowered; selfing \\
\hline $\begin{array}{l}\text { S. siphocampy- } \\
\text { loides Vatke }\end{array}$ & 22 & $\begin{array}{l}\mathrm{CA} \text {; Sierra foot- } \\
\text { hills and Coast } \\
\text { ranges }\end{array}$ & $\begin{array}{l}\text { mixed conifer and oak } \\
\text { woodlands; various } \\
\text { substrates }\end{array}$ & $\begin{array}{l}\text { long-flowered; outcross- } \\
\text { ing }\end{array}$ \\
\hline S. tuberosa Benth. & 6 & $\begin{array}{l}\text { Coast ranges of } \\
\text { CA and south- } \\
\text { ern OR }\end{array}$ & chaparral & $\begin{array}{l}\text { short-flowered; some } \\
\text { selfing }\end{array}$ \\
\hline
\end{tabular}

ping banding patterns between isozymes (6Pgd-1 and 6Pgd-2). Apparent duplicate gene loci were observed for the dimeric enzymes IDH (Idh-1 and Idh-2) and MDH (Mdh-1 and $M d h-2)$. For IDH, the minimum electrophoretic pattern consisted of three bands, whereas for MDH, a consistent pattern of three or more bands was observed for a pair of polymorphic loci; the other MDH loci varied independently. All other enzymes exhibit numbers of loci typically reported for genetically diploid plants (Gottlieb, 1981, 1982).

Allelic Diversity Among Loci. -All 18 isozyme loci were polymorphic in one or more species, when the $99 \%$ criterion was applied (Gottlieb, 1981). In all, 97 alleles were detected, with the number of alleles per locus ranging from two alleles for $M d h-5$ to 13 alleles for Pgi-2 (mean of 5.4 alleles detected per locus). The number of taxa for which a given locus is polymorphic ranges from one taxon for $M d h-5$ and Tpi-2 to nine taxa for Pgi-2 (mean of 4.7 taxa polymorphic per locus). Three of the 18 loci examined ( $M d h$ 5, Pgm-2, and Tpi-2) have the same allele present at highest frequency in all ten taxa, while two loci (Pgi-2 and $S k d h)$ have as many as six different alleles predominating in different taxa.

The effective number of alleles provides a measure of allelic evenness and equals the observed number of alleles only when all alleles are present in equal frequencies. Fourteen of 18 loci in the $S$. angustifolia complex have an effective number of alleles less than two, indicating that most of the allelic diversity at these loci is in the form of alleles at low frequency, with one allele predominating in most populations. Four 
TABLE 2. Allele frequencies for ten taxa of Scutellaria. Taxon abbreviations: $\mathrm{ANG}=S$. angustifolia angustifolia, $\mathrm{MIC}=S$. a. micrantha, $\mathrm{ANT}=S$. antirrhinoides, $\mathrm{BOL}=S$. bolanderi, $\mathrm{BRI}=S$. brittonii, $\mathrm{CAL}=S$. californica, $\mathrm{NAN}=S$. nana, $\mathrm{SAP}=S$. sapphirina, $\mathrm{SIP}=S$. siphocampyloides, and $\mathrm{TUB}=S$. tuberosa $($ see Table 1$)$.

\begin{tabular}{|c|c|c|c|c|c|c|c|c|c|c|c|c|}
\hline \multirow[b]{3}{*}{ Locus } & \multirow[b]{3}{*}{ Allele } & \multicolumn{11}{|c|}{ Allele frequency } \\
\hline & & \multicolumn{10}{|c|}{ Taxon } & \multirow{2}{*}{$\begin{array}{l}\text { Mean of } \\
\text { all pop- } \\
\text { ulations }\end{array}$} \\
\hline & & ANG & MIC & ANT & BOL & BRI & CAL & NAN & SAP & SIP & TUB & \\
\hline Aat -1 & $\begin{array}{l}a \\
b \\
c \\
d\end{array}$ & $\begin{array}{c}0.260 \\
\overline{-} \\
0.677 \\
0.063\end{array}$ & $\begin{array}{c}- \\
\overline{-} \\
0.962 \\
0.038\end{array}$ & $\begin{array}{c}\overline{-} \\
\overline{-} \\
1.000\end{array}$ & $\begin{array}{c}1.000 \\
- \\
- \\
-\end{array}$ & $\frac{-}{-}$ & $\begin{array}{c}\overline{-} \\
0 . \overline{222} \\
0.778\end{array}$ & $\begin{array}{c}- \\
\overline{-} \\
1.000 \\
-\end{array}$ & $\begin{array}{c}\overline{-} \\
- \\
-\end{array}$ & $\begin{array}{c}\overline{-} \\
\overline{0} 042 \\
0.958\end{array}$ & $\begin{array}{c}- \\
\overline{1} \\
- \\
-\end{array}$ & $\begin{array}{l}0.124 \\
0.075 \\
0.389 \\
0.412\end{array}$ \\
\hline Aat -2 & $\begin{array}{l}a \\
b \\
c \\
d \\
e\end{array}$ & $\begin{array}{c}- \\
\overline{-} \\
0.844 \\
0.156 \\
-\end{array}$ & $\begin{array}{c}\overline{-} \\
1.000 \\
- \\
-\end{array}$ & $\begin{array}{c}0.004 \\
- \\
0.977 \\
0.019 \\
-\end{array}$ & $\begin{array}{c}\overline{-} \\
\overline{-} \\
\overline{-} \\
1.000\end{array}$ & $\begin{array}{c}-\overline{146} \\
0.854 \\
- \\
-\end{array}$ & $\begin{array}{c}\overline{-} \\
\overline{1.000} \\
- \\
-\end{array}$ & $\begin{array}{c}- \\
\overline{-} \\
0.733 \\
0.267 \\
-\end{array}$ & $\begin{array}{c}\overline{-} \\
\overline{-} \\
1.000 \\
-\end{array}$ & $\begin{array}{c}0.065 \\
- \\
0.935 \\
- \\
-\end{array}$ & $\begin{array}{c}- \\
\overline{-} \\
1.000 \\
-\end{array}$ & $\begin{array}{l}0.014 \\
0.004 \\
0.709 \\
0.179 \\
0.094\end{array}$ \\
\hline Acn-l & $\begin{array}{l}a \\
b \\
c\end{array}$ & $\begin{array}{c}0.975 \\
0.025 \\
-\end{array}$ & $\begin{array}{c}1.000 \\
- \\
-\end{array}$ & $\begin{array}{c}0.834 \\
0.166 \\
-\end{array}$ & $\begin{array}{c}0.008 \\
0.992 \\
-\end{array}$ & $\begin{array}{c}\overline{-} \\
- \\
-\end{array}$ & $\begin{array}{l}0.008 \\
0.964 \\
0.028\end{array}$ & $\begin{array}{l}\overline{-} \\
0.997 \\
0.003\end{array}$ & $\begin{array}{c}\overline{0_{0}} \\
-\end{array}$ & $\begin{array}{c}\overline{1.000} \\
-\end{array}$ & $\begin{array}{c}\overline{-} \\
-\end{array}$ & $\begin{array}{l}0.305 \\
0.691 \\
0.004\end{array}$ \\
\hline Acn-2 & $\begin{array}{l}a \\
b \\
c \\
d\end{array}$ & $\begin{array}{c}0.237 \\
0.763 \\
- \\
-\end{array}$ & $\begin{array}{c}0 . \overline{6} 19 \\
-\overline{381} \\
0.01\end{array}$ & $\begin{array}{c}\overline{1.000} \\
- \\
-\end{array}$ & $\begin{array}{c}- \\
\overline{-} \\
- \\
-\end{array}$ & $\begin{array}{c}\overline{-} \\
1.000 \\
- \\
-\end{array}$ & $\begin{array}{c}0.101 \\
0.893 \\
0.006 \\
-\end{array}$ & $\begin{array}{c}-\overline{939} \\
0.061 \\
-\end{array}$ & $\begin{array}{c}\overline{-} \\
1.000 \\
- \\
-\end{array}$ & $\begin{array}{c}\overline{-} \\
1.000 \\
-\end{array}$ & $\begin{array}{c}0.584 \\
0.416 \\
- \\
-\end{array}$ & $\begin{array}{l}0.071 \\
0.781 \\
0.101 \\
0.047\end{array}$ \\
\hline $\mathrm{Fe}-1$ & $\begin{array}{l}a \\
b \\
c \\
d\end{array}$ & $\begin{array}{c}-\overline{926} \\
0.074 \\
-\end{array}$ & $\begin{array}{l}-\overline{9} \\
0.919 \\
0.004 \\
0.077\end{array}$ & $\begin{array}{c}0 . \overline{944} \\
0.056 \\
-\end{array}$ & $\begin{array}{c}\overrightarrow{1.000} \\
- \\
-\end{array}$ & $\begin{array}{c}\overline{-} \\
1.000 \\
-\end{array}$ & $\begin{array}{c}0.177 \\
0.813 \\
0.010 \\
-\end{array}$ & $\begin{array}{c}0 . \overline{444} \\
0.494 \\
0.062\end{array}$ & $\begin{array}{c}1 . \overline{000} \\
- \\
-\end{array}$ & $\begin{array}{c}0.028 \\
0.732 \\
0.240 \\
-\end{array}$ & $\begin{array}{c}- \\
\overline{-} \\
1.000 \\
-\end{array}$ & $\begin{array}{l}0.026 \\
0.757 \\
0.201 \\
0.016\end{array}$ \\
\hline$I d h-I$ & $\begin{array}{l}a \\
b \\
c \\
d\end{array}$ & $\begin{array}{c}- \\
0.969 \\
0.031 \\
-\end{array}$ & $\begin{array}{c}0.019 \\
0.981 \\
- \\
-\end{array}$ & $\begin{array}{c}-\overline{000} \\
- \\
-\end{array}$ & $\begin{array}{c}\overline{-} \\
1.000 \\
- \\
-\end{array}$ & $\begin{array}{c}\overline{-} \\
1.000 \\
- \\
-\end{array}$ & $\begin{array}{c}-\overline{9} \\
0.994 \\
\overline{-006}\end{array}$ & $\begin{array}{c}\overline{-} \\
1.000 \\
- \\
-\end{array}$ & $\begin{array}{c}\overline{-} \\
1.000 \\
-\end{array}$ & $\begin{array}{c}0.018 \\
0.955 \\
0.027 \\
-\end{array}$ & $\begin{array}{c}- \\
- \\
\overline{1} .000\end{array}$ & $\begin{array}{l}0.006 \\
0.928 \\
0.009 \\
0.057\end{array}$ \\
\hline$I d h-2$ & $\begin{array}{l}a \\
b \\
c \\
d \\
e \\
f\end{array}$ & $\begin{array}{c}- \\
\overline{-} \\
0.969 \\
0.031 \\
- \\
-\end{array}$ & $\begin{array}{c}- \\
0.019 \\
0.981 \\
- \\
- \\
-\end{array}$ & $\begin{array}{c}- \\
\overline{-} \\
0.994 \\
\overline{-} \\
\overline{-} \\
0.006\end{array}$ & $\begin{array}{c}- \\
\overline{-} \\
1.000 \\
- \\
- \\
-\end{array}$ & $\begin{array}{c}- \\
- \\
1.000 \\
- \\
- \\
-\end{array}$ & $\begin{array}{c}- \\
\overline{-} \\
0.979 \\
0.021 \\
- \\
-\end{array}$ & $\begin{array}{c}0.042 \\
- \\
0.958 \\
- \\
- \\
-\end{array}$ & $\begin{array}{c}- \\
\overline{-} \\
1.000 \\
- \\
- \\
-\end{array}$ & $\begin{array}{c}- \\
\overline{-} \\
0.955 \\
0.045 \\
- \\
-\end{array}$ & $\begin{array}{c}- \\
- \\
- \\
\overline{-} \\
1.000 \\
-\end{array}$ & $\begin{array}{l}0.004 \\
0.002 \\
0.921 \\
0.015 \\
0.057 \\
0.001\end{array}$ \\
\hline$M d h-1$ & $\begin{array}{l}a \\
b \\
c \\
d \\
e \\
f \\
g\end{array}$ & $\begin{array}{c}0.679 \\
- \\
0.321 \\
- \\
- \\
- \\
-\end{array}$ & $\begin{array}{c}0.661 \\
- \\
0.339 \\
- \\
- \\
- \\
-\end{array}$ & $\begin{array}{c}0.022 \\
- \\
0.619 \\
- \\
0.359 \\
- \\
-\end{array}$ & $\begin{array}{c}- \\
\overline{-} \\
1.000 \\
\overline{-} \\
\overline{-} \\
-\end{array}$ & $\begin{array}{c}0 . \overline{281} \\
0.719 \\
- \\
- \\
- \\
-\end{array}$ & $\begin{array}{c}\overline{-} \\
0 . \overline{12} \\
\overline{-} \\
0.083 \\
\overline{-} \\
0.005\end{array}$ & $\begin{array}{c}- \\
\overline{-} \\
0.357 \\
\overline{-} \\
0.643 \\
- \\
-\end{array}$ & $\begin{array}{c}\overline{-} \\
\overline{-} \\
0.125 \\
0.875 \\
- \\
-\end{array}$ & $\begin{array}{c}- \\
\overline{-} \\
0.992 \\
\overline{-} \\
0.008 \\
- \\
-\end{array}$ & $\begin{array}{c}- \\
\overline{-} \\
- \\
\overline{-} \\
1.000 \\
-\end{array}$ & $\begin{array}{l}0.160 \\
0.008 \\
0.591 \\
0.009 \\
0.174 \\
0.057 \\
0.001\end{array}$ \\
\hline$M d h-2$ & $\begin{array}{l}a \\
b \\
c \\
d \\
e\end{array}$ & $\begin{array}{c}1 . \overline{000} \\
- \\
-\end{array}$ & $\begin{array}{c}1.000 \\
- \\
- \\
-\end{array}$ & $\begin{array}{c}1.000 \\
- \\
- \\
-\end{array}$ & $\begin{array}{c}0 . \overline{900} \\
- \\
\overline{-} \\
0 . \overline{100}\end{array}$ & $\begin{array}{c}0.281 \\
0.719 \\
- \\
- \\
-\end{array}$ & $\begin{array}{c}\overline{-} \\
1.000 \\
- \\
-\end{array}$ & $\begin{array}{c}0 . \overline{997} \\
\overline{-} \\
0.003 \\
-\end{array}$ & $\begin{array}{c}\overline{0} . \overline{973} \\
\overline{-} \\
0.027 \\
-\end{array}$ & $\begin{array}{c}\overline{-} \\
1.000 \\
- \\
-\end{array}$ & $\begin{array}{c}\overline{-} \\
1.000 \\
- \\
-\end{array}$ & $\begin{array}{l}0.008 \\
0.924 \\
0.057 \\
0.002 \\
0.009\end{array}$ \\
\hline$M d h-3$ & $\begin{array}{l}a \\
b \\
c \\
d \\
e \\
f\end{array}$ & $\begin{array}{c}\overline{-} \\
1.000 \\
- \\
- \\
- \\
-\end{array}$ & $\begin{array}{c}0.057 \\
0.866 \\
- \\
- \\
- \\
0.077\end{array}$ & $\begin{array}{c}\overline{-} \\
1.000 \\
- \\
- \\
-\end{array}$ & $\begin{array}{c}\overline{-} \\
0.950 \\
- \\
\overline{-} \\
0.050 \\
-\end{array}$ & $\begin{array}{c}1.000 \\
= \\
- \\
-\end{array}$ & $\begin{array}{c}0.005 \\
0.995 \\
= \\
- \\
-\end{array}$ & $\begin{array}{c}\overline{-} \\
0.977 \\
\overline{-} \\
0.023 \\
- \\
-\end{array}$ & $\begin{array}{c}0 . \overline{977} \\
\overline{-} \\
0.023 \\
\overline{-} \\
-\end{array}$ & $\begin{array}{c}\overline{-} \\
= \\
- \\
- \\
-\end{array}$ & $\begin{array}{c}\overline{-} \\
\overline{1.000} \\
- \\
- \\
-\end{array}$ & $\begin{array}{l}0.007 \\
0.918 \\
0.057 \\
0.004 \\
0.005 \\
0.009\end{array}$ \\
\hline$M d h-4$ & $\begin{array}{l}a \\
b \\
c\end{array}$ & $\begin{array}{c}\overline{1.000} \\
-\end{array}$ & $\begin{array}{c}\overline{-} \\
1.000 \\
-\end{array}$ & $\begin{array}{c}\overline{-} \\
-\end{array}$ & $\frac{-}{1.000}$ & $\begin{array}{c}\overline{-} \\
-\end{array}$ & $\begin{array}{c}0.057 \\
0.943 \\
-\end{array}$ & $\begin{array}{c}\overline{-} \\
-\end{array}$ & $\begin{array}{c}\overline{-} \\
-\end{array}$ & $\begin{array}{c}0.023 \\
0.977 \\
-\end{array}$ & $\frac{\overline{-}}{1.000}$ & $\begin{array}{l}0.011 \\
0.838 \\
0.151\end{array}$ \\
\hline
\end{tabular}


TABLE 2. Continued.

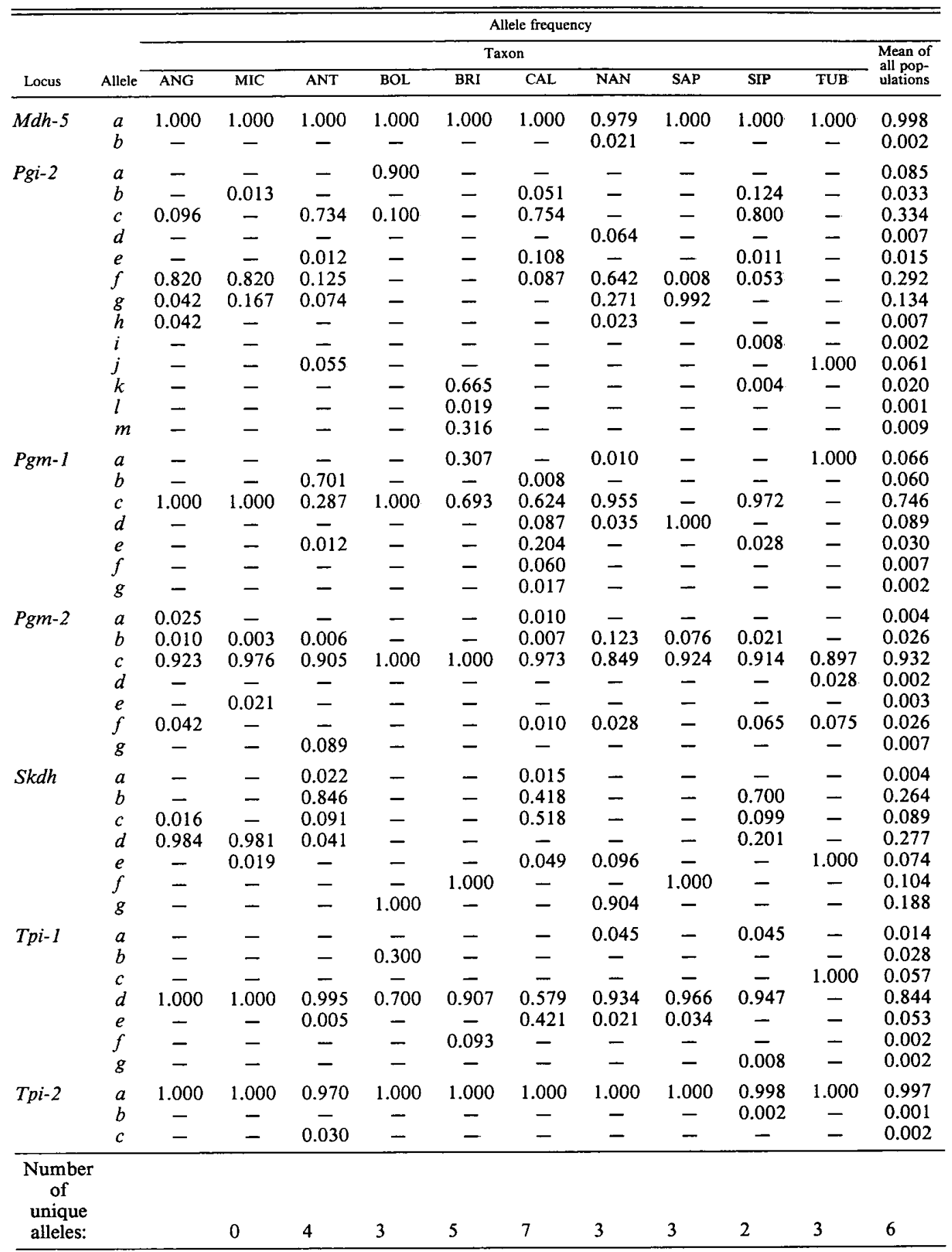


TABLE 3. Summary of genetic variability in ten taxa of Scutellaria: total number of alleles per taxon $\left(A_{t}\right)$, mean number of alleles per locus $(A)$, mean number of alleles per polymorphic locus $\left(A_{\mathrm{p}}\right)$, effective number of alleles $\left(n_{\mathrm{e}}\right)$, percentage of loci polymorphic per taxon $\left(P_{\mathrm{s}} ; 99 \%\right.$ criterion), mean percentage of loci polymorphic per population $\left(P_{\mathrm{p}} ; 99 \%\right.$ criterion), observed heterozygosity $\left(H_{\mathrm{o}}\right)$, expected heterozygosity $\left(H_{\mathrm{e}}\right)$, Wright's fixation index $(F)$, with the number of populations for which $F$ is calculated $(N)$ and the standard deviation of $F$.

\begin{tabular}{|c|c|c|c|c|c|c|c|c|c|c|c|}
\hline \multirow[b]{2}{*}{ Taxon } & \multirow[b]{2}{*}{$A_{\mathrm{t}}$} & \multirow[b]{2}{*}{$A$} & \multirow[b]{2}{*}{$A_{\mathrm{p}}$} & \multirow[b]{2}{*}{$n_{\mathbf{e}}$} & \multirow[b]{2}{*}{$P_{s}$} & \multirow[b]{2}{*}{$P_{\mathrm{p}}$} & \multirow[b]{2}{*}{$H_{0}$} & \multirow[b]{2}{*}{$H_{\mathrm{e}}$} & \multicolumn{3}{|c|}{ Wright's fixation index } \\
\hline & & & & & & & & & $F$ & $N$ & SD \\
\hline S. angustifolia & 34 & 1.89 & 2.45 & 1.20 & 61.11 & 18.06 & 0.088 & 0.078 & 0.018 & 5 & 0.465 \\
\hline S. a. micrantha & 32 & 1.78 & 2.40 & 1.16 & 55.56 & 6.81 & 0.022 & 0.029 & 0.631 & 4 & 0.380 \\
\hline S. antirrhinoides & 38 & 2.11 & 2.90 & 1.21 & 55.56 & 19.84 & 0.067 & 0.073 & 0.319 & 6 & 0.299 \\
\hline S. bolanderi & 23 & 1.28 & 2.00 & 1.07 & 22.22 & 8.35 & 0.030 & 0.023 & - & 0 & - \\
\hline S. brittonii & 25 & 1.39 & 2.17 & 1.19 & 33.33 & 20.37 & 0.064 & 0.094 & 0.042 & 3 & 0.552 \\
\hline S. californica & 46 & 2.56 & 3.17 & 1.33 & 66.67 & 31.94 & 0.114 & 0.125 & 0.071 & 8 & 0.164 \\
\hline S. nana & 38 & 2.11 & 2.50 & 1.27 & 66.67 & 31.73 & 0.106 & 0.123 & 0.138 & 6 & 0.237 \\
\hline S. sapphirina & 24 & 1.33 & 2.00 & 1.04 & 27.78 & 7.80 & 0.020 & 0.021 & 0.035 & 4 & 0.368 \\
\hline S. siphocampyloides & 40 & 2.22 & 2.82 & 1.16 & 61.11 & 11.12 & 0.046 & 0.043 & -0.024 & 7 & 0.148 \\
\hline S. tuberosa & 21 & 1.17 & 2.50 & 1.07 & 11.11 & 7.43 & 0.052 & 0.031 & -0.330 & 2 & 0.330 \\
\hline Overall: & 32.1 & 1.78 & 2.79 & 1.17 & 46.11 & 17.01 & 0.064 & 0.067 & 0.119 & 45 & \\
\hline
\end{tabular}

loci (Aat-1, Mdh-1, Pgi-2, and Skdh) have effective numbers of alleles ranging from 2.45 to 4.85 , indicating a broader distribution of genetic diversity.

Genetic Variability Among Taxa.-The total number of alleles detected per taxon $\left(A_{\imath}\right)$ ranges from 21 (1.17 alleles per locus) in $S$. tuberosa to 46 (2.56 alleles per locus) in $S$. californica. The mean number of alleles per polymorphic locus ranges from the minimum possible of 2.0 for $S$. bolanderi and $S$. sapphirina to 3.17 for $S$. californica. The mean effective number of alleles per locus for each taxon ranges from 1.04 for $S$. sapphirina and 1.07 in S. tuberosa and $S$. bolanderi to 1.33 in $S$. californica (Table $3)$. The mean percentage of loci polymorphic per population $\left(P_{\mathrm{p}}\right)$ for the entire group is 17.0 (Table 3 ). The range of mean values for $P_{\mathrm{p}}$ for individual taxa varies from $6.81 \%$ for $S$. angustifolia micrantha to $31.94 \%$ for $S$. californica. The mean percentage of loci polymorphic at the species or subspecies level $\left(P_{s}\right)$ for all taxa is 46.1 , with values for individual taxa ranging from $11 \%$ for $S$. $t u$ berosa to $67 \%$ for $S$. californica and $S$. nana (Table 3 ). The mean observed heterozygosity $\left(H_{\mathrm{o}}\right)$ for all populations is 0.064 . Mean values for taxa in the complex vary more than fivefold from 0.020 for $S$. sapphirina to 0.114 for $S$. californica. Mean expected heterozygosity estimates $\left(H_{\mathrm{e}}\right)$ vary similarly from 0.021 for $S$. sapphirina to 0.125 for $S$. californica.
Comparing values of Wright's fixation in$\operatorname{dex}(F)$ between populations or taxa provides a relative measure of the degree of inbreeding that may result from differences in breeding system or from population subdivision. A value of zero signifies random mating. The mean $F$ value for all populations considered is 0.119 . Values of $F$ for taxa in the $S$. angustifolia complex range from -0.330 for $S$. tuberosa to 0.631 for $S$. angustifolia micrantha (Table 3). Since the error resulting from the sampling of clonally related individuals within a population sample is likely to lower the estimate of $H_{\mathrm{c}}$ relative to $H_{\mathrm{o}}$, many $F$ values reported here are likely to underestimate true values of $F$. Therefore, negative values of $F$ probably do not represent selection favoring heterozygotes or the result of negative assortative mating. Positive values of $F$ may result from partial selfing and from substructuring of the population due to nonrandom dispersal of seeds and pollen (Levin and Kerster, 1974) and subsequent increases in consanguineous matings or from matings between genetically identical clonal replicates.

Genetic Differentiation.-Genetic-diversity analysis by means of hierarchical $F$ statistics can be used to assess genetic differentiation among a complex of species descended from a common ancestor (Wright, 1965, 1978; Nei, 1973). For the analysis of the $S$. angustifolia complex, three hierarchical categories were defined: popu- 
TABle 4. Summary of genetic diversity (Nei, 1973) and differentiation at all loci among taxa in the Scutellaria angustifolia complex: total genetic diversity $\left(H_{\mathrm{t}}\right)$, population-level genetic diversity $\left(H_{\mathrm{p}}\right)$, population differentiation $\left(D_{\mathrm{ps}}\right)$, species-level (or subspecies-level) genetic diversity $\left(H_{\mathrm{s}}\right)$, species differentiation $\left(D_{\mathrm{st}}\right)$, and apportionment of genetic diversity within populations $\left(H_{\mathrm{p}} / H_{\mathrm{t}}\right)$, among populations within taxa $\left(D_{\mathrm{ps}} / H_{\mathrm{t}}\right)$, and among $\operatorname{taxa}\left(D_{\mathrm{st}} / H_{\mathrm{t}}\right)$.

\begin{tabular}{|c|c|c|c|c|c|c|c|c|}
\hline \multirow[b]{2}{*}{ Locus } & \multirow[b]{2}{*}{$H_{t}$} & \multirow[b]{2}{*}{$H_{\mathrm{p}}$} & \multirow[b]{2}{*}{$D_{\mathrm{ps}}$} & \multirow[b]{2}{*}{$H_{\mathrm{s}}$} & \multirow[b]{2}{*}{$D_{\text {st }}$} & \multicolumn{3}{|c|}{ Proportion of genetic diversity } \\
\hline & & & & & & $\begin{array}{c}\text { Within } \\
\text { populations }\end{array}$ & $\begin{array}{c}\text { Among } \\
\text { populations } \\
\text { within taxa }\end{array}$ & $\underset{\text { taxa }}{\text { Among }}$ \\
\hline Aat -1 & 0.6018 & 0.0327 & 0.0766 & 0.1093 & 0.4925 & 0.054 & 0.128 & 0.818 \\
\hline Aat -2 & 0.4139 & 0.0816 & 0.0721 & 0.1537 & 0.2602 & 0.197 & 0.174 & 0.629 \\
\hline Acn-1 & 0.4359 & 0.0247 & 0.0325 & 0.0572 & 0.3787 & 0.057 & 0.074 & 0.869 \\
\hline Acn-2 & 0.2863 & 0.0596 & 0.1207 & 0.1803 & 0.1060 & 0.208 & 0.422 & 0.370 \\
\hline $\mathrm{Fe}-1$ & 0.4256 & 0.1200 & 0.1387 & 0.2587 & 0.1669 & 0.282 & 0.326 & 0.392 \\
\hline$I d h-1$ & 0.1476 & 0.0257 & 0.0337 & 0.0594 & 0.0882 & 0.174 & 0.229 & 0.597 \\
\hline$I d h-2$ & 0.1682 & 0.0319 & 0.0515 & 0.0834 & 0.0848 & 0.190 & 0.306 & 0.504 \\
\hline$M d h-1$ & 0.5943 & 0.1116 & 0.1411 & 0.2527 & 0.3415 & 0.188 & 0.237 & 0.575 \\
\hline$M d h-2$ & 0.1596 & 0.0253 & 0.0239 & 0.0492 & 0.1104 & 0.159 & 0.149 & 0.692 \\
\hline$M d h-3$ & 0.1682 & 0.0329 & 0.0446 & 0.0775 & 0.0908 & 0.195 . & 0.265 & 0.540 \\
\hline$M d h-4$ & 0.1585 & 0.0052 & 0.0011 & 0.0063 & 0.1522 & 0.033 & 0.007 & 0.960 \\
\hline$M d h-5$ & 0.0077 & 0.0061 & 0.0016 & 0.0077 & 0.0000 & 0.802 & 0.198 & 0.000 \\
\hline$P g i-2$ & 0.7665 & 0.2064 & 0.1766 & 0.3830 & 0.3835 & 0.269 & 0.231 & 0.500 \\
\hline Pgm-1 & 0.4586 & 0.0895 & 0.0892 & 0.1787 & 0.2800 & 0.195 & 0.195 & 0.610 \\
\hline$P g m-2$ & 0.1493 & 0.1088 & 0.0405 & 0.1493 & 0.0000 & 0.729 & 0.271 & 0.000 \\
\hline Skdh & 0.7850 & 0.1002 & 0.1388 & 0.2390 & 0.5460 & 0.128 & 0.176 & 0.696 \\
\hline$T p i-1$ & 0.2450 & 0.0678 & 0.0677 & 0.1355 & 0.1145 & 0.271 & 0.271 & 0.458 \\
\hline$T p i-2$ & 0.0106 & 0.0084 & 0.0022 & 0.0106 & 0.0000 & 0.798 & 0.202 & 0.000 \\
\hline $\begin{array}{l}\text { Overall } \\
\text { (across loci): }\end{array}$ & 0.3326 & 0.0632 & 0.0695 & 0.1327 & 0.1999 & 0.190 & 0.209 & 0.601 \\
\hline
\end{tabular}

lation, species (or subspecies), and total clade. The amount of genetic diversity within each category in ascending order in the hierarchy is represented by $H_{\mathrm{p}}, H_{\mathrm{s}}$, and $H_{\mathrm{i}}$. The results of the genetic-diversity analysis are shown for each locus separately and for all 18 loci combined (Table 4). Single-locus estimates of total genetic diversity range from 0.008 for $M d h-5$ to 0.785 for $S k d h$, with a mean for all loci of 0.333 . The sampled loci exhibit a range of levels of differentiation among taxa. Averaging all 18 loci, $60.1 \%$ of the total genetic diversity is the result of differentiation among the ten taxa in the $S$. angustifolia complex, $20.9 \%$ is the result of differentiation among populations within species or subspecies, and the remaining $19.0 \%$ represents the portion of total diversity that exists as variation among individuals within populations.

Hierarchical $F$ statistics also were calculated for each taxon individually (Table 5). Values of $H_{\mathrm{t}}$ range from 0.027 for $S$. sapphirina, indicating that it is the most genetically homogeneous taxon, to 0.181 for $S$. californica, with a mean value for all ten taxa of 0.111 . Differentiation among populations within a species is designated $G_{\mathrm{pt}}$ ( $F_{\mathrm{st}}$ of Wright [1965]). Estimates of population differentiation range from $18.7 \%$ for S. tuberosa to $75.5 \%$ for $S$. angustifolia $m i$ crantha with a mean of $42.1 \%$ for all ten taxa (Table 5).

Genetic Identity.-Within each taxon, mean genetic identities, shown on the diagonal in Table 6, range from 0.907 for $S$. californica to 0.983 for $S$. tuberosa, with a mean for all ten taxa of 0.941 . Interspecific genetic identities within the $S$. angustifolia complex also are similar to those reported from other studies, but with a somewhat lower average identity. Genetic similarities between taxa range from 0.203 to 0.911 (for the two subspecies of $S$. angustifolia), with a mean genetic identity for all pairwise species comparisons of 0.617 compared to 0.67 reported by Gottlieb (1981) for congeneric genetic identities.

\section{Discussion}

Substantial variation in the extent and distribution of genetic variability exists 
TABLE 5. Summary of genetic diversity (Nei, 1973) and differentiation for ten taxa of the S. angustifolia complex: total genetic diversity $\left(H_{\mathrm{t}}\right)$, population-level genetic diversity $\left(H_{\mathrm{p}}\right)$, and apportionment of genetic diversity within populations $\left(H_{\mathrm{p}} / H_{\mathrm{t}}\right)$ and among populations $\left(G_{\mathrm{pt}}\right)$.

\begin{tabular}{lcccc}
\hline \multicolumn{1}{c}{ Taxon } & $H_{\mathrm{t}}$ & $H_{\mathrm{p}}$ & $H_{\mathrm{p}} / H_{\mathrm{t}}$ & $G_{\mathrm{pt}}$ \\
\hline S. angustifolia angustifolia & 0.1306 & 0.0798 & 0.611 & 0.389 \\
S. a. micrantha & 0.1072 & 0.0263 & 0.245 & 0.755 \\
S. antirrhinoides & 0.1377 & 0.0724 & 0.526 & 0.474 \\
S. bolanderi & 0.0812 & 0.0227 & 0.280 & 0.720 \\
S. brittonii & 0.1170 & 0.0927 & 0.792 & 0.208 \\
S. californica & 0.1813 & 0.1291 & 0.712 & 0.288 \\
S. nana & 0.1745 & 0.1174 & 0.673 & 0.327 \\
S. sapphirina & 0.0271 & 0.0209 & 0.770 & 0.230 \\
S. siphocampyloides & 0.1134 & 0.0422 & 0.372 & 0.628 \\
S. tuberosa & 0.0373 & 0.0303 & 0.813 & 0.187 \\
\hline Mean: & 0.1107 & 0.0634 & 0.579 & 0.421 \\
\hline
\end{tabular}

among species in the Scutellaria angustifolia complex. This variation in genetic variability in a clade that exhibits a diversity of habitats, breeding systems, and distributional ranges provides the opportunity to examine the relative importance of these taxon-specific characteristics (Table 1) to the extent and distribution of genetic diversity in plant species. The fact that these species have a well-understood phylogenetic history based on isozyme and morphological data (Olmstead, 1989) makes this an exceptional opportunity, because the relative importance of phylogenetic relatedness also can be considered (see Felsenstein, 1985).

Breeding System and Genetic Diversity.High levels of heterozygosity and polymorphism and low levels of population differentiation $\left(G_{\mathrm{pt}}\right)$ have been associated with predominantly outbreeding plant species, whereas total genetic diversity $\left(H_{t}\right)$ is not substantially correlated with breeding system (Gottlieb, 1981; Loveless and Hamrick, 1984). This generally is true in the $S$. angustifolia complex; however, the direct comparison of heterozygosity, polymorphism, and population differentiation for assessing breeding systems is restricted in its application by the interaction of factors that influence genetic structure in populations. The effect of such interactions can be illustrated by examples from Scutellaria.

Phylogenetic history can influence specieslevel polymorphism and total genetic variability. The two subspecies of Scutellaria angustifolia exhibit contrasting breeding systems; subspecies angustifolia is large- flowered and outcrossing, while subspecies micrantha is small-flowered and largely selfing. These taxa have similar values for $H_{t}$, but the large-flowered subspecies has levels of heterozygosity four times greater $(0.088$ vs. 0.022) than the small-flowered subspecies and retains more than three times the genetic diversity in the average population $\left(H_{\mathrm{p}}\right)$ than does its small-flowered relative $(0.080$ vs. 0.026$)$. Polymorphism at the population level also is higher in subspecies angustifolia (18.1\% vs. $6.8 \%$ ), as predicted, whereas polymorphism at the taxon level $\left(P_{\mathrm{s}}\right)$ is not substantially different between the two taxa (61.1\% vs. $55.6 \%)$. The comparison of taxon-level polymorphism between these two subspecies differs from the expectation of greater polymorphism in the more outcrossing subspecies (Gottlieb, 1981) but can be explained readily. From the phylogenetic analysis of the group (Olmstead, 1989), it can be inferred that the largeflowered subspecies is derived from the small-flowered subspecies (unlike the more common occurrence of small-flowered selfers derived from large-flowered outcrossers). Populations of the small-flowered subspecies micrantha each retain less genetic variability than a typical population of the large-flowered subspecies angustifolia, but the cumulative polymorphism $\left(P_{\mathrm{s}}\right)$ and total genetic diversity $\left(H_{\mathrm{t}}\right)$ are similar in the two subspecies.

Differences in the extent of geographic distribution may cause conclusions about breeding systems that are based on levels of heterozygosity and polymorphism to be 
TABle 6. Mean genetic identities (Nei, 1978) within taxa (along diagonal) and between taxa of the Scutellaria angustifolia complex.

\begin{tabular}{|c|c|c|c|c|c|c|c|c|c|c|}
\hline \multirow[b]{2}{*}{ Taxon } & \multicolumn{10}{|c|}{ Taxon } \\
\hline & 1 & 2 & 3 & 4 & 5 & 6 & 7 & 8 & 9 & 10 \\
\hline 1) $S$. angustifolia angus & & & & & & & & & & \\
\hline tifolia & 0.927 & & & & & & & & & \\
\hline 2) S. a. micrantha & 0.911 & 0.911 & & & & & & & & \\
\hline 3) $S$. antirrhinoides & 0.762 & 0.737 & 0.923 & & & & & & & \\
\hline 4) $S$. bolanderi & 0.579 & 0.547 & 0.553 & 0.968 & & & & & & \\
\hline 5) $S$. brittonii & 0.667 & 0.641 & 0.736 & 0.568 & 0.958 & & & & & \\
\hline 6) $S$. californica & 0.727 & 0.704 & 0.832 & 0.630 & 0.758 & 0.907 & & & & \\
\hline 7) $S$. nana & 0.769 & 0.759 & 0.706 & 0.649 & 0.756 & 0.766 & 0.925 & & & \\
\hline 8) $S$. sapphirina & 0.615 & 0.586 & 0.650 & 0.531 & 0.674 & 0.662 & 0.711 & 0.981 & & \\
\hline 9) S. siphocampyloides & 0.740 & 0.712 & 0.849 & 0.637 & 0.819 & 0.893 & 0.770 & 0.648 & 0.925 & \\
\hline 10) S. tuberosa & 0.246 & 0.234 & 0.203 & 0.278 & 0.333 & 0.271 & 0.356 & 0.297 & 0.260 & 0.983 \\
\hline
\end{tabular}

misleading. Scutellaria nana is a widespread, relatively common species throughout the Great Basin, whereas $S$. sapphirina is a narrowly restricted species consisting of isolated populations in the mountains of eastern Nevada. Levels of heterozygosity and polymorphism are much higher in $S$. nana than in its sister species, S. sapphirina. Also, there is less differentiation among populations of $S$. nana than among those of $S$. sapphirina, thus suggesting that there is more inbreeding in $S$. sapphirina. However, greater total genetic diversity and polymorphism are commonly associated with greater geographic distribution (Loveless and Hamrick, 1984; Karron, 1987); consequently, a direct comparison of these values will not provide a valid assessment of breeding systems in two species with such large differences in distribution. The phylogenetic analysis of the group (Olmstead, 1989 ) implies that $S$. sapphirina may be the progenitor of $S$. nana. This suggests that the greater differentiation among populations of $S$. sapphirina could be the result of a long history of population isolation, whereas the lesser differentiation among populations of the widespread $S$. nana may reflect recent colonization of its present range.

The highest values for Wright's fixation index are found in the two small, blue-flowered taxa, S. antirrhinoides of northern California and $S$. angustifolia micrantha of eastern Oregon and adjacent Nevada and Idaho. In California, S. antirrhinoides has a large-flowered sister taxon, $S$. siphocampyloides, and in eastern Oregon, $S$. angus- tifolia micrantha has a large-flowered sister taxon, $S$. a. angustifolia. In each region, the small-flowered taxon exhibits a much higher $F$ value than the large-flowered taxon $(0.319$ vs. -0.024 in California and 0.631 vs. 0.018 in eastern Oregon). This suggests that there are differences in breeding system between members of each pair of taxa, with the smallflowered taxon exhibiting a substantial amount of inbreeding and the large-flowered taxon mating essentially at random. Greenhouse studies are consistent with this hypothesis: the small-flowered plants exhibit a greater amount of autogamous seed production in an insect-free greenhouse than do the large-flowered plants (Olmstead, 1988).

Two species, $S$. californica and $S$. nana, exhibit levels of total diversity $\left(H_{0}\right)$, population-level diversity $\left(H_{\mathrm{p}}\right)$, heterozygosity, and polymorphism that are very similar to each other and substantially higher than any of the other species in the group (Tables 3, 5 ); yet these two species are very dissimilar morphologically, ecologically, and geographically. Both species have small flowers that are similar in size to other less genetically variable species in the group. The similarity in genetic variability between these two species may be coincidental; however, they share white flowers, a character of potential significance to reproductive biology (blue flowers are typical of most other species in the group). It is possible that an insect pollinator common to these two white-flowered species may result in greater outbreeding than for the blue-flowered species (ad- 
ditional data on pollinators for these species are needed to test this hypothesis). Alternatively, shared flower color may be coincidental, and the similarity in genetic variability between these species may reflect present or historical factors related to population size or life history traits.

Geographic Distribution and Genetic Diversity. - The generality of restricted genetic variability in species with narrow distributions (Hamrick et al., 1979; Karron, 1987) is consistent with the evidence from the $S$. angustifolia complex. The taxa with the most restricted ranges have the highest intraspecific genetic identities (Table 6), and three of these ( $S$. bolanderi, $S$. sapphirina, and $S$. tuberosa) have the lowest estimates of total genetic diversity $\left(H_{t}\right)$ in the group.

Sampling design is particularly important when the question of interest involves the relationship between geographic distribution and genetic variability. In this study of ten taxa, estimated values for three parameters of genetic variability that are often used for comparison between species (mean number of alleles per locus, the mean number of alleles per polymorphic locus, and the percentage of polymorphic loci per species) (Hamrick et al., 1979; Gottlieb, 1981; Hamrick, 1983; Vogelmann and Gastony, 1987; Karron, 1987) exhibit positive correlations with the number of populations sampled, although only one of the three correlations is significant at the $P<0.05$ level (mean number of alleles per locus, $r=0.612$, $P<0.1$; mean number of alleles per polymorphic locus, $r=0.444, P<0.01$; percentage of polymorphic loci per species, $r=$ $0.624, P<0.1)$. These results are consistent with statistical sampling theory (Larsen and Marx, 1981), which predicts that, as the number of samples increases, a greater portion of the total variability will be encountered. This suggests that the use of these genetic-variability estimates should be limited to comparisons between species for which a similar number of populations have been sampled (Crawford et al., 1984).

The geographic distribution of the sampled populations may be another confounding factor. Populations sampled from a narrowly restricted species may be much closer geographically and could be genetically more homogeneous due to gene flow or historical reasons than are widely scattered populations of a widespread species (Karron et al., 1988). Similarly, the degree of genetic differentiation among populations within a species $\left(F_{\text {ST }}\right.$ of Wright [1965]), another estimate frequently used for species comparisons (Hamrick, 1983; Loveless and Hamrick, 1984), was found to exhibit a significant positive correlation with the number of populations sampled $(r=0.849, P<0.05)$ for nine taxa in Scutellaria (omitting $S$. bolanderi, for which the two population samples represent two subspecific taxa). It is unclear to what extent this correlation is a function of the number of populations sampled or whether it is the result of the close proximity of the small number of populations sampled for narrowly restricted species or of other unrelated variables.

Considering two estimates of genetic variability that are not correlated with number of populations sampled in this study, the most narrowly restricted species $(S$. bolanderi, S. sapphirina, and $S$. tuberosa) exhibit the lowest values of $H_{\mathrm{t}}$ and $H_{\mathrm{p}}$ (Table $5)$. These results suggest that, in the $S$. angustifolia complex, restriction in geographic range is associated with reduced levels of genetic variability and that this reduced variability is not simply a reflection of the close proximity of the sampled populations.

Knowledge of breeding system and geographic range does not always allow one to predict levels of genetic diversity. Scutellaria siphocampyloides is a widespread, large-flowered, primarily outcrossing species that is characterized by unexpectedly low levels of total genetic diversity and heterozygosity and a relatively high degree of differentiation among populations. A very low value for Wright's fixation index and lack of autogamous seed set in greenhouse-grown plants (Olmstead, 1988) indicate that this taxon is highly outcrossing relative to other taxa in the group. An explanation for the apparently anomalous data observed for $S$. siphocampyloides may lie in the history of the population dynamics within that taxon. A combination of factors including greater clonal reproduction, smaller average natural population sizes, and frequent occurrences of population extirpation and recolonization among small isolated populations could keep the level of observed genetic di- 
versity low, relative to the expected level for a species exhibiting the life-history characteristics of $S$. siphocampyloides.

Habitat Specificity and Genetic Diversity. - Conifer woodlands are the preferred habitats of four taxa, while three taxa inhabit sagebrush desert (Table 1). Within each of these two contrasting habitat types, taxa exhibit widely divergent estimates for almost every genetic-diversity parameter measured, suggesting that shared habitat preference does not imply an adaptive value for any particular level of genetic diversity measured. If the extent and distribution of genetic variability can be considered a consequence of environment and life-history strategy, one may expect species with similar habitat specificities to exhibit similar levels of genetic diversity. However, the results of this study are consistent with the studies reviewed by Hamrick et al. (1979), who found no significant difference associated with habitat type for three commonly reported estimates of genetic diversity.

Genetic Differentiation Within and Among Species.-Hierarchical $F$ statistics and genetic identity provide complementary insight into the genetic structure of a species. Hierarchical $F$ statistics estimate the degree to which the total genetic variability of a species can be accounted for within populations and between populations, whereas genetic identity (Nei, 1978) estimates the degree of genetic similarity between individual populations. The relatively high levels of $G_{\mathrm{pt}}$ exhibited by most species of the $S$. angustifolia complex, compared to most other studies (Hamrick, 1983; Loveless and Hamrick, 1984; Wendel and Parks, 1985), may represent a combination of factors including a substantial amount of selfing in many populations and the effect of genetic drift on the small, widely-scattered populations that characterize most species of Scutellaria.

Genetic identities among conspecific populations in a wide variety of flowering plants generally range from 0.90 to 1.00 , averaging about 0.95 (Gottlieb, 1981; Crawford, 1983); this reflects closely the variation observed in the $S$. angustifolia complex (mean $I=0.941$ ). Genetic identities within and among species and subspecies of Scutellaria (mean intertaxon $I=$
0.617 ) are typical of continental species groups (Crawford, 1983). The average value for congeneric genetic identities reported by Gottlieb $(I=0.67)$ is probably inflated to a certain degree, because many previous studies have examined congeneric species that were believed in advance to be closely related species-pairs. It should be noted that this group of ten closely related taxa represents only a small part of the diversity within Scutellaria, which is world-wide in distribution, and that the average genetic identities among taxa within the entire genus would be much lower, probably below the level of resolution obtainable by isozyme electrophoresis, due to the confounding effects of convergent and identical electromorphs. The danger of drawing general conclusions regarding the genetic similarity of congeneric species is brought into focus when the present study is contrasted with studies such as those of the Hawaiian species of Tetramolopium (Lowrey and Crawford, 1985) and Bidens (Helenurm and Ganders, 1985). In these studies, the genetic similarity among all populations within each group (seven species of Tetramolopium and 15 species of Bidens) shows no greater differentiation than that found among populations within most single species of Scutellaria.

Whereas genetic identity and other measures of genetic similarity or distance have been used frequently to express the genetic relationship among a group of species, the use of hierarchical $F$ statistics to assess the genetic structure of species groups has been uncommon (Bruederle and Fairbrothers, 1986). Therefore, no comparable body of information on the apportionment of total genetic diversity into within-species and among-species components during the course of phylogenetic radiations in plants is available. Three studies in which hierarchical $F$ statistics have been used to assess genetic structure in an entire clade of plants are available for comparison. Differentiation between species accounts for $5.3 \%$ of the total genetic diversity in a clade of eight taxa in Sedum (M. F. Denton and Olmstead, unpubl.), $51.6 \%$ in a clade of four taxa in Carex (Bruederle and Fairbrothers, 1986), and $62.5 \%$ in this study of ten taxa in $\mathrm{Scu}$ tellaria. It is evident from this small number 


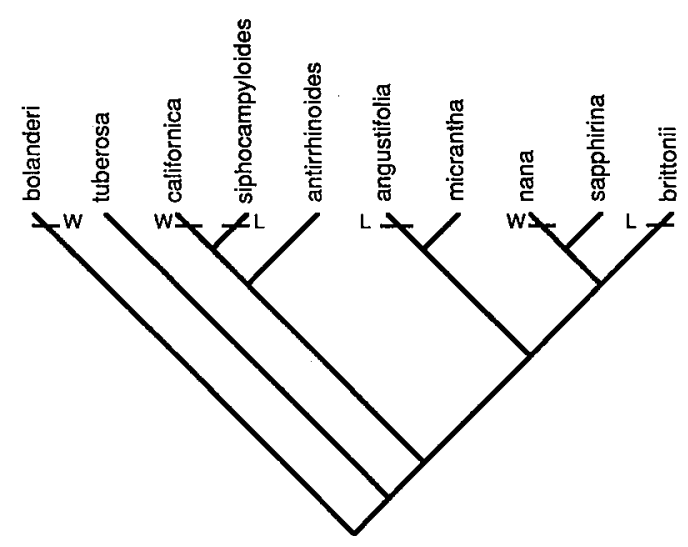

FIG. 2. Reconstruction of the phylogeny of the Scutellaria angustifolia complex showing the evolution of long flowers (L) and white corolla color (W).

of studies that considerable variation exists in the genetic structure of plant speciesgroups and that more such studies are needed before generalizations can be made.

Phylogenetic Relationship and Genetic Diversity. - The effect of phylogenetic relationship on the extent and distribution of genetic variation in related plant species has not been examined previously within the context of genetic-diversity statistics. To the extent that characters of reproductive morphology are conservative indicators of phylogenetic relatedness as well as of population genetic structure through their relationship to breeding systems, one may expect that closely related species would exhibit similar genetic-diversity statistics. In a study of genetic divergence among six species of Layia, estimates of heterozygosity, polymorphism, and the number of alleles per polymorphic locus indicated that the most closely related species also have the most similar estimates of genetic variability (Warwick and Gottlieb, 1985). In contrast, close phylogenetic relationship is not correlated with similarity in observed levels of genetic diversity in the $S$. angustifolia complex.

The reason for the lack of correspondence between phylogenetic relatedness and genetic variability among species of Scutellaria is evident when one considers the evolution of reproductive characters in the group (Fig. 2). Two characters of reproductive morphology that may have a substan- tial effect on breeding system (flower color and corolla length) represent multiple cases of parallel evolution within the group. White flower color and long corollas have evolved independently in three separate lineages during the phylogenetic radiation of the group from an ancestor inferred to have short blue flowers (Olmstead, 1989). Many of the observed differences in genetic diversity among species are correlated with flower color and corolla length. White-flowered species, except the narrowly restricted and genetically depauperate $S$. bolanderi, exhibit the highest levels of genetic diversity among the taxa examined. Plants with long corollas generally exhibit higher levels of heterozygosity and polymorphism than the short-flowered plants. Within each of three species-groups within the $S$. angustifolia complex (Fig. 2), there are taxa with divergent values for many genetic-diversity statistics, suggesting that evolution has affected the extent and distribution of genetic variation within species of the $S$. angustifolia complex in many ways.

\section{Conclusions}

A combination of factors, biological and historical, influences the extent and distribution of genetic diversity within and among species of the $S$. angustifolia complex. In this clade of ten taxa, $60.1 \%$ of the total genetic diversity represents differentiation among species, $20.9 \%$ represents differentiation among populations within species, and the remaining $19.0 \%$ resides within populations. Too few studies of clade-level genetic structure have been carried out for comparisons to suggest which factors influence the distribution of genetic diversity at this level.

The results of this study suggest the following conclusions regarding the factors that influence genetic diversity in species of the $S$. angustifolia complex. 1) Differences in breeding system account for most of the observed variation in genetic diversity among species and are reflected primarily in the estimates of heterozygosity, population-level polymorphism, inbreeding (Wright's fixation index, $F$ ), and population differentiation. 2) The extent of a species' geographic range influences genetic diversity in species 
with narrowly restricted distributions, resulting in lower estimated values for total genetic diversity, population-level genetic diversity, and population-level polymorphism. 3) The very different habitat preferences characterizing species in the $S$. angustifolia complex appear to have little or no influence on the extent or distribution of genetic diversity within species occupying different habitats. 4) Phylogenetic relatedness does not imply any similarity in genetic structure among species. It is not clear whether this last conclusion is a general one regarding the phylogenetic significance of genetic diversity; the amount of parallel evolution within the group could make the $S$. angustifolia complex a special case. It appears that genetic-diversity statistics are constrained by the phylogenetic history of species only insofar as the characters affecting reproductive biology are similarly constrained.

\section{ACKNOWLEDGMENTS}

I thank M. Denton, A. Kruckeberg, W. DiMichele, A. Kohn, J. Ammirati, D. Soltis, P. Soltis, J. Felsenstein, J. Karron, R. Burnham, and an anonymous reviewer for stimulating discussions and comments on drafts of this manuscript. This research was supported by NSF Doctoral Dissertation Grant BSR-8501045 and research grants from Sigma $\mathrm{Xi}$ and the Hardman Foundation.

\section{Literature CITED}

BAyer, R. J., AND D. J. Crawford. 1986. Allozyme divergence among five diploid species of Antennaria (Asteraceae: Inuleae) and their allopolyploid relatives. Amer. J. Bot. 73:287-289.

Brown, C. R., AND S. K. JAIN. 1979. Reproductive system and pattern of genetic variation in two Limnanthes species. Theoret. Appl. Genet. 54:181-190.

Brutderle, L. P., AND D. E. Fatrbrothers. 1986. Allozyme variation in populations of the Carex crinita complex (Cyperaceae). Syst. Bot. 11:583594.

Crawford, D. J. 1983. Phylogenetic and systematic inferences from electrophoretic studies, pp. 257287. In S. O. Tanksley and T. J. Orton (eds.), Isozymes in Plant Genetics and Breeding, Part A. Elsevier, Amsterdam, Neth.

Crawford, D. J., AND E. B. Smith. 1982a. Allozyme variation in Coreopsis nuecensoides and $C$. nuecensis (Compositae), a progenitor-derivative species pair. Evolution 36:379-386.

- 1982b. Allozyme divergence between Core- opsis basalis and C. wrightii (Compositae). Syst. Bot. 7:359-364.

- 1984. Allozyme divergence and intraspecific variation in Coreopsis grandiflora (Compositae). Syst. Bot. 9:219-225.

Crawford, D. J., E. B. Smith, and R. E. Pilatowski. 1984. Isozymes of Coreopsis section Calliopsis (Compositae): Genetic variation within and divergence among the species. Brittonia 36:375-381.

Crawford, D. J., T. F. Stuessy, and M. Silva O. 1987. Allozyme divergence and the evolution of Dendroceris (Compositae: Lactuceae). Syst. Bot. 12: 435-443.

Crawford, D. J., AND H. D. Wirson. 1979. Allozyme variation in several closely related diploid species of Chenopodium of the western United States. Amer. J. Bot. 66:237-244.

Felsenstein, J. 1985. Phylogenies and the comparative method. Amer. Natur. 125:1-15.

GotTliEB, L. D. 1973. Genetic differentiation, sympatric speciation, and the origin of a diploid species of Stephanomeria. Amer. J. Bot. 60:545-553.

- 1974. Allelic diversity in the outcrossing annual plant Stephanomeria exigua ssp. carotifera (Compositae). Evolution 29:213-225.

- 1981. Electrophoretic evidence and plant populations. Prog. Phytochem. 7:1-46.

1982. Conservation and duplication of isozymes in plants. Science 216:373-380.

- 1984. Electrophoretic analysis of the phylogeny of the self-pollinating populations of Clarkia xantiana. Plant Syst. Evol. 147:91-102.

GotTlieb, L. D., S. I. Warwick, and V. S. Ford. 1985. Morphological and electrophoretic divergence between Layia discoidea and L. glandulosa. Syst. Bot. 10:484-495.

HAMRICK, J. L. 1983. The distribution of genetic variation within and among natural plant populations, pp. 335-348. In C. M. Schonewald-Cox, S. M. Chambers, G. MacBryde, and L. Thomas (eds.), Genetics and Conservation. Benjamin/Cummings, Menlo Park, CA.

Hamrick, J. L., Y. B. Linhart, AND J. B. MitTon. 1979. Relationships between life history characteristics and electrophoretically detectable genetic variation in plants. Ann. Rev. Ecol. Syst. 10:173200.

Helenurm, K., AND F. R. GANDERs. 1985. Adaptive radiation and genetic differentiation in Hawaiian Bidens. Evolution 39:753-765.

Hiebert, R. D., AND J. L. Hamrick. 1983. Patterns and levels of genetic variation in Great Basin Bristlecone Pine, Pinus longaeva. Evolution 37:302310.

KARRON, J. D. 1987. A comparison of levels of genetic polymorphism and self-incompatibility in geographically restricted and widespread plant congeners. Evol. Ecol. 1:47-58.

Karron, J. D., Y. B. Linhart, C. A. Chaulk, and C. A. ROBERTSON. 1988. Genetic structure of populations of geographically restricted and widespread species of Astragalus (Fabaceae). Amer. J. Bot. 75: 1114-1119.

Kimura, M., AND J. F. Crow. 1964. The number of alleles that can be maintained in a finite population. Genetics 99:725-738. 
Larsen, R. A., AND M. L. Marx. 1981. An Introduction to Mathematical Statistics and Its Applications. Prentice-Hall, Englewood Cliffs, NJ.

LAyton, C. R., AND F. R. GANDERs. 1984. The genetic consequences of contrasting breeding systems in Plectritis (Valerianaceae). Evolution 38:13081325.

Levin, D. A., ANd H. W. Kerster. 1974. Gene flow in plants. Evol. Biol. 7:139-220.

Loveless, M. D., AND J. L. HAMRICK. 1984. Ecological determinants of genetic structure in plant populations. Ann. Rev. Ecol. Syst. 15:65-95.

Lowrey, T. K., AND D. J. CRAwFord. 1985. Allozyme divergence and evolution in Tetramolopium (Compositae: Astereae) on the Hawaiian Islands. Syst. Bot. 10:64-72.

Manos, P. S., AND D. E. Fairbrothers. 1987. Allozyme variation in populations of six northeastern American red oaks (Fagaceae: Quercus subg. Erythrobalanus). Syst. Bot. 12:365-373.

NeI, M. 1973. Analysis of gene diversity in subdivided populations. Proc. Nat. Acad. Sci. USA 70: 3321-3323.

- 1978. Estimation of average heterozygosity and genetic distance from a small number of individuals. Genetics 89:583-590.

Nevo, E., A. BeIles, ANd R. Ben-Shlomo. 1984. The evolutionary significance of genetic diversity: Ecological, demographic and life history correlates, $\mathrm{pp}$. 13-213. In G. S. Mani (ed.), Evolutionary dynamics of Genetic Diversity. Lecture notes in biomathematics 53. Springer-Verlag, Berlin, W. Ger.

Olmstead, R. G. 1988. Systematics, genetic diversity analysis, and phylogeny of the Scutellaria angustifolia complex (Labiatae). Ph.D. Diss. Univ. Washington, Seattle.

. 1989. Phylogeny, phenotypic evolution and biogeography of the Scutellaria angustifolia complex: Inference from morphological and molecular data. Syst. Bot. 14:320-338.
RieseberG, L. H., AND D. E. Soltis. 1987. Allozymic differentiation between Tolmiea menziesii and Tellima grandiflora (Saxifragaceae). Syst. Bot. 12:154161.

Schonewald-Cox, C. M., S. M. Chambers, B. MACBRyde, AND L. Thomas. 1983. Genetics and Conservation. Benjamin/Cummings, Menlo Park, CA.

Soltis, D. E., C. J. Haufler, D. C. Darrow, and G. J. GASTONY. 1983. Starch gel electrophoresis of ferns: A compilation of grinding buffers, gel and electrode buffers, and staining schedules. Amer. Fern J. 73:9-27.

Soltis, D. E., AND P. S. Soltis. 1987. Breeding system of the fern Dryopteris expansa: Evidence for mixed mating. Amer. J. Bot. 74:504-509.

SwoFFord, D. L., AND R. B. SELANDER. 1981. BIOSYS-1: A FORTRAN program for the comprehensive analysis of electrophoretic data in population genetics and systematics. J. Hered. 72:281-283.

Vogelmann, J. E., AND G. J. Gastony. 1987. Electrophoretic enzyme analysis of North American and eastern Asian populations of Agastache sect. Agastache (Labiatae). Amer. J. Bot. 74:385-393.

WARwICK, S. I., AND L. D. GotTlieb. 1985. Genetic divergence and geographic speciation in Layia (Compositae). Evolution 39:1236-1241.

Wendel, J. F., AND C. R. PARKs. 1985. Genetic diversity and population structure in Camellia japonica L. (Theaceae). Amer. J. Bot. 72:52-65.

WRIGHT, S. 1951. The genetical structure of populations. Ann. Eugen. 15:323-354.

- 1965. The interpretation of population structure by F-statistics with special regard to systems of mating. Evolution 19:395-420.

- 1978. Evolution and the Genetics of Populations, Vol. 4. Variability Within and Among Natural Populations. Univ. Chicago Press, Chicago, IL.

Corresponding Editor: J. L. Hamrick 


\section{APPENDIX}

Populations and sample sizes $(N)$ of Scutellaria surveyed for electrophoretic variation are given in the table below. All collections by R. G. Olmstead. Vouchers deposited at the University of Washington Herbarium.

\begin{tabular}{|c|c|c|c|}
\hline Taxon & Population & $N$ & Collection number(s) \\
\hline S. angustifolia angustifolia & $\begin{array}{l}\text { Anson Wright Park, OR } \\
\text { Mitchell Summit, OR } \\
\text { Mitchell, OR } \\
\text { Antelope, OR } \\
\text { Fairview Campground, OR } \\
\text { Spray, OR } \\
\text { Maury Mts. 1, OR } \\
\text { Maury Mts. 2, OR } \\
\text { Kendrick, ID } \\
\text { Orofino, ID } \\
\text { Kamiah, ID } \\
\text { Lyle, WA }\end{array}$ & $\begin{array}{r}5 \\
4 \\
8 \\
5 \\
10 \\
22 \\
10 \\
5 \\
4 \\
4 \\
1 \\
8\end{array}$ & $\begin{array}{l}301,302 \\
315 \\
318 \\
499 \\
638 \\
640 \\
700 \\
702 \\
551 \\
552 \\
553 \\
692\end{array}$ \\
\hline S. a. micrantha & $\begin{array}{l}\text { Idlewyld Campground, OR } \\
\text { Princeton Jct., OR } \\
\text { Page Spring, Frenchglen, OR } \\
\text { Silvies River, OR } \\
\text { Steens Mt., OR } \\
\text { Cow Lake, OR } \\
\text { Succor Creek, OR } \\
\text { Ruby Mts., NV } \\
\text { Independence Mts., NV } \\
\text { Jack Creek, NV } \\
\text { Wild Horse Dam, NV } \\
\text { Emigrant Pass, NV } \\
\text { Santa Rosa Mts., NV }\end{array}$ & $\begin{array}{r}3 \\
4 \\
18 \\
9 \\
10 \\
11 \\
8 \\
10 \\
2 \\
3 \\
7 \\
14 \\
12\end{array}$ & $\begin{array}{l}333 \\
348 \\
351,709 \\
636 \\
715 \\
729 \\
733 \\
618 \\
622 \\
624 \\
630 \\
631 \\
632\end{array}$ \\
\hline S. antirrhinoides & $\begin{array}{l}\text { Miranda, CA } \\
\text { Van Duzen River, CA } \\
\text { Coffee Creek, CA } \\
\text { Big Flat, CA } \\
\text { Sawyer's Bar, CA } \\
\text { Rogue River, OR } \\
\text { Rogue River Trail, OR } \\
\text { Canyon Creek Trail, CA } \\
\text { Snow Mt., CA }\end{array}$ & $\begin{array}{r}9 \\
5 \\
13 \\
2 \\
3 \\
11 \\
9 \\
14 \\
11\end{array}$ & $\begin{array}{l}421 \\
429 \\
461 \\
465 \\
472 \\
656 \\
654 \\
680 \\
878\end{array}$ \\
\hline S. bolanderi & $\begin{array}{l}\text { Mt. Bullion, CA } \\
\text { Groveland, CA } \\
\text { Vallecitos, CA } \\
\text { Sheep Ranch, CA } \\
\text { Toll House, CA } \\
\text { Watts Valley Rd., CA } \\
\text { Linns Valley, CA } \\
\text { Wawona, CA } \\
\text { Idylwild, CA }\end{array}$ & $\begin{array}{l}3 \\
4 \\
3 \\
4 \\
1 \\
1 \\
1 \\
1 \\
6\end{array}$ & $\begin{array}{l}374 \\
386 \\
390 \\
395 \\
569 \\
570 \\
821 \\
836 \mathrm{~b} \\
803\end{array}$ \\
\hline S. brittonii & $\begin{array}{l}\text { Stateline, hwy. 287, CO } \\
\text { Ward, CO } \\
\text { Vedawoo, WY }\end{array}$ & $\begin{array}{r}9 \\
12 \\
5\end{array}$ & $\begin{array}{l}641 \\
642 \\
645\end{array}$ \\
\hline S. californica & $\begin{array}{l}\text { Bartlett Springs, CA } \\
\text { Ripstein Camp, CA } \\
\text { Canyon Creek, CA } \\
\text { Blue Oak Campground, CA } \\
\text { Indian Valley, CA } \\
\text { Willits, CA } \\
\text { Snow Mt., CA } \\
\text { Summit Springs, Snow Mt., CA } \\
\text { Van Duzen Bridge, CA } \\
\text { Whitehall, CA } \\
\text { Oregon Creek, CA } \\
\text { Yuba River, CA }\end{array}$ & $\begin{array}{r}16 \\
4 \\
12 \\
13 \\
17 \\
2 \\
2 \\
8 \\
5 \\
13 \\
9 \\
2\end{array}$ & $\begin{array}{l}371,668 \\
678 \\
454,682 \\
534,673 \\
666 \\
542 \\
870 \\
881 \\
888 \\
402,837 \\
839 \\
844\end{array}$ \\
\hline
\end{tabular}


APPENDIX. Continued.

\begin{tabular}{|c|c|c|c|}
\hline Taxon & Population & $N$ & Collection number(s) \\
\hline S. nana & $\begin{array}{l}\text { Princeton Jct., OR } \\
\text { Fields, OR } \\
\text { Prineville Reservoir, OR } \\
\text { Steens Mt., OR } \\
\text { Hart Mt. 1, OR } \\
\text { Hart Mt. 2, OR } \\
\text { Adel, OR } \\
\text { Susanville, CA } \\
\text { Rye Patch Rd. 1, CA } \\
\text { Rye Patch Rd. 2, CA } \\
\text { Fernley, NV }\end{array}$ & $\begin{array}{r}2 \\
13 \\
12 \\
18 \\
13 \\
8 \\
10 \\
2 \\
2 \\
3 \\
8\end{array}$ & $\begin{array}{l}350 \\
359,728 \\
693 \\
726 \\
750 \\
751 \\
754 \\
415 \\
581 \\
584 \\
588\end{array}$ \\
\hline S. sapphirina & $\begin{array}{l}\text { Hunts Canyon Guard Station, NV } \\
\text { Little Antelope Summit, NV } \\
\text { Cottonwood Creek, NV } \\
\text { Ellison Guard Station, NV } \\
\text { White River Narrows, NV } \\
\text { White River Campground, NV } \\
\text { Currant Summit, NV } \\
\text { Schell Creek Range, NV }\end{array}$ & $\begin{array}{r}8 \\
10 \\
1 \\
1 \\
1 \\
11 \\
11 \\
12\end{array}$ & $\begin{array}{l}595 \\
596 \\
600 \\
606 \\
607 \\
609 \\
614 \\
615\end{array}$ \\
\hline S. siphocampyloides & $\begin{array}{l}\text { Calaveras, CA } \\
\text { Butte Meadows, CA } \\
\text { Post Creek, CA } \\
\text { Peanut, CA } \\
\text { Junction City, CA } \\
\text { Oakhurst, CA } \\
\text { Bass Lake, CA } \\
\text { Alder Spring, CA } \\
\text { Sequoia National Park, CA } \\
\text { Butts Canyon Rd., CA } \\
\text { Walker Ridge Rd. 1, CA } \\
\text { Walker Ridge Rd. 2, CA } \\
\text { Blue Oak Campground, CA } \\
\text { Sespe Creek, CA } \\
\text { Tule Creek, CA } \\
\text { Chilao, CA } \\
\text { Horse Flats, CA } \\
\text { San Jacinto Mts., CA } \\
\text { San Bernardino Mts., CA } \\
\text { Kennedy Meadows, CA } \\
\text { Greenhorn Summit, CA } \\
\text { Wofford Heights }\end{array}$ & $\begin{array}{r}4 \\
2 \\
12 \\
6 \\
12 \\
2 \\
6 \\
2 \\
3 \\
12 \\
10 \\
11 \\
7 \\
10 \\
1 \\
12 \\
4 \\
8 \\
10 \\
8 \\
3 \\
3\end{array}$ & $\begin{array}{l}396 \\
418 \\
438,676 \\
447 \\
677 \\
562 \\
564 \\
568 \\
571 \\
574,669 \\
663 \\
665 \\
671 \\
782 \\
785 \\
792 \\
794 \\
804 \\
807 \\
813 \\
826 \\
828\end{array}$ \\
\hline S. tuberosa & $\begin{array}{l}\text { Long Point 1, CA } \\
\text { Long Point 2, CA } \\
\text { Walker Ridge, CA } \\
\text { Cow Mt., CA } \\
\text { Willow Creek, CA } \\
\text { Forest hwy. 7, Elk Creek, CA }\end{array}$ & $\begin{array}{r}2 \\
7 \\
21 \\
3 \\
1 \\
15\end{array}$ & $\begin{array}{l}512 \\
515 \\
522,524 \\
536 \\
544 \\
660\end{array}$ \\
\hline
\end{tabular}

